Reprod. Nutr. Dévelop., 1980, 20 (3 B), 817-826.

\title{
Importance of the characteristics of the young in the manifestation and establishment of maternal behaviour in sheep
}

\author{
par P. POINDRON, P. LE NEINDRE *, Ildiko RAKSANYI, G. TRILLAT *, P. ORGEUR \\ Laboratoire de Comportement Animal, I.N.R.A. \\ Nouzilly 37380 Monnaie \\ * Laboratoire de la Production de Viande, I.N.R.A. \\ Theix 63110 Beoumont, France.
}

Summary. The role played by the lamb in the regulation of maternal behaviour of the ewe around parturition was investigated in three experiments. In the first, the spontaneous manifestation of that behaviour was observed in parturient ewes when their lambs were swapped with either newborn or 12 to 24-hr old alien lambs. The ewes were undisturbed, or only slightly so, when their lambs were exchanged for alien newborn. In contrast, very obvious and significant differences were observed when swapping involved 12 to 24-hr old lambs. In the second experiment, ewes totally separated from their lambs at birth and for $12 \mathrm{hrs}$ accepted a newborn alien lamb more readily than their own 12-hr old lamb at the time of reunion. In the third experiment, ewes were maintained in partial contact whit their lambs for $12 \mathrm{hrs}$ and maternal behaviour was tested at that time. The ewes remained maternal up to the time of testing only if they could smell their lambs. It was concluded that some characteristics of the newborn lamb are necessary for the development of adequate maternal behaviour.

\section{Introduction.}

In sheep the onset of maternal behaviour is closely associated with parturition. At lambing the ewe immediately starts to lick the newborn lamb with the emission of lowpitch bleats (Collias, 1956 ; Hersher, Richmond and Moore, 1963) and suckles the young within one to two hours (Hulet, Alexander and Hafez, 1975). Maternal behaviour can be seen even before parturition (Alexander, 1960 ; Arnold and Morgan, 1975), apparently in association with the presence of oestrogens in maternal blood (Poindron and Le Neindre, 1979). These facts suggest that the birth of the newborn stimulates a pre-existing responsiveness in the dam. But the appearance of young not only allows the manifestation of maternal behaviour but also starts to influence the development of that behaviour. As the lamb changes rapidly in aspect and behaviour (Hulet ef al., 1975), it is likely that the characteristics of the newborn are of some importance in the display of an adequate maternal behaviour at parturition (Collias, 1956 ; Hersher et al., 1963). In the present paper, we report three separate experiments 
in which the young have been found to influence the following aspects of maternal behaviour :

- spontaneous maternal responsiveness at parturition ;

- fading of maternal responsiveness after parturition (sensitive period) ;

- maintenance of responsiveness beyond the initial limits of the sensitive period.

\section{Experiment I : Influence of the characteristics of the young on manifestation of maternal behaviour in parturient ewes.}

To assess the importance of the age of the lamb (newborn versus 12 to 24-hrs old) in the manifestation of maternal behaviour, the lamsb of parturient ewes were exchanged with either a newborn (less than $15 \mathrm{~min}$ old and never licked by its own dam) or a 12 to 24 -hr old alien lamb (hereafter referred to as an « aged » lamb). The lambs were swapped either at birth before the ewes had any contact with their own lambs (single or multiple births, group 1), after an initial mother-young contact of 30 min (single births only, group 2) or at the birth of the second lamb, the first lamb then remaining with its dam (multiple births, group 3). Each of these groups was divided into 3 classes :

a. - lamb exchanged with a newborn alien,

b. - lamb exchanged with an «aged » alien,

c. - controls (no exchange).

The animals were put into a $2 \times 2 \mathrm{~m}$ closed space for observation when parturition was imminent. This space was inside the pen holding the rest of the pregnant flock, so that the experimental animals knew the place and were surrounded by familiar animals.

During swapping, the ewe was held lying down by one observer while another advanced with the alien lamb behind his back and took the ewe's own lamb away. From this time on, the behaviour of the dam was recorded $(20 \mathrm{~min}$ in group 1 and 10 min in groups 2 and 3). Licking time was measured with a stop watch and aggressive behaviour, type of bleats emitted by the dam (low and/or high) and behaviour during sucking were noted. Alien newborn lambs were provided by ewes in the same flock, « aged lambs » being taken away from their own dams just at the time of testing.

We used multiparous Préalpes-du-Sud ewes kept permanently in sheds on zero grazing management. Reproductive cycles were synchronized at oestrus and parturition was induced with $15 \mathrm{mg}$ of dexamethasone i. $\mathrm{m} .(3 \mathrm{mg} / \mathrm{ml}$ Dexafort-Intervet) given on day 144 p. m. (normal length of pregnancy $=146$ days). This method of inducing parturition is thought to mimic the normal endocrine events of lambing (Bosc, 1974) and has not been found to affect maternal behaviour (Poindron, Martin and Hooley, 1979).

The results of the three groups are summarized in tables 1,2 and 3. When the lambs were swapped at the birth of the first lamb (group 1), the ewes provided with a newborn alien did not differ from the controls in any of the behavioural traits studied (licking, aggression or bleating; table 1). The proportion of ewes which accepted a lamb with no disturbance, as estimated by any of the above mentioned traits, was 
10 out of 11 ewes given a newborn alien versus 23/23 controls (Fisher one-tailed exact probability : $\mathrm{P}=0.3)$. In contrast, the group in which the lamb of the ewe was exchanged for an «aged» alien lamb differed significantly from the other two groups in all of the characteristics studied, and only 6 out of 16 ewes readily accepted an alien (versus 10/11 and 23/23:P=0.03 and $P=0.0002$, respectively).

TABLE 1

Effect of exchanging the lamb of a dam with an alien lamb on maternal behaviour:

A. Swapping at the birth of the first lamb (single or twin births)

\begin{tabular}{|c|c|c|c|c|}
\hline Group & $\begin{array}{l}\text { Licking time } \\
\text { over a period } \\
\text { of } 20 \mathrm{~min} . \\
\text { (in min. } \pm \mathrm{SE} \text { ) }\end{array}$ & $\begin{array}{c}\text { Incidence } \\
\text { of aggressive } \\
\text { behaviour } \\
(p .100)\end{array}$ & $\begin{array}{l}\text { Proportion of } \\
\text { ewes bleating } \\
\text { low pitch only } \\
\text { (p. 100) }\end{array}$ & $\begin{array}{l}\text { Proportion of ewes } \\
\text { having shown no } \\
\text { sign of disturbance } \\
\text { in any studied } \\
\text { elements }\end{array}$ \\
\hline \multirow{3}{*}{$\begin{array}{l}\text { Swapping with a newborn } \\
\text { alien lamb, } n=11 \ldots \ldots \\
\text { Swapping with a } 12 \text { to } 24-\mathrm{hr} \\
\text { old alien lamb, } n=16 \ldots \\
\text { Controls (no swapping), } \\
n=23 \quad \ldots \ldots \ldots \ldots \ldots\end{array}$} & $13.9 \pm 1.0\left(^{a}\right)$ & $9\left(^{a}\right)$ & $91(a)$ & $91(a)$ \\
\hline & $5.2 \pm 1.2\left(^{b}\right)$ & $50\left(^{b}\right)$ & $12\left(^{b}\right)$ & $37(b)$ \\
\hline & $14.2 \pm 0.6\left(^{a}\right)$ & $0\left({ }^{a}\right)$ & $100\left(^{a}\right)$ & $100\left(^{a}\right)$ \\
\hline
\end{tabular}

Same superscript in parenthesis of a same column indicates there is no significant difference between those values at the 5 p. 100 level.

When the lambs were exchanged after an initial motheryoung contact of $30 \mathrm{~min}$, newborn lambs were still better accepted than «aged 》 lambs (see table 2), as in the case of swapping at parturition. The ewes offered an «aged 》 lamb differed in all respects from the other two groups (0/11 acceptances without signs of disturbance versus $3 / 6$ for the group «swapping for a newborn » and $6 / 6$ for the controls ;

TABLE 2

Effect of exchonging the lamb of a dam with an alien lamb on maternal behaviour:

B. Swapping after an initial mother-young contact of $30 \mathrm{~min}$. (single births only)

\begin{tabular}{|c|c|c|c|c|}
\hline Group & $\begin{array}{l}\text { Licking time } \\
\text { over a period } \\
\text { of } 10 \mathrm{~min} . \\
\text { (in min. } \pm \mathrm{SE} \text { ) }\end{array}$ & $\begin{array}{c}\text { Incidence } \\
\text { of agressive } \\
\text { behaviour } \\
\text { (p. 100) }\end{array}$ & $\begin{array}{l}\text { Proportion of } \\
\text { ewes bleating } \\
\text { low pitch only } \\
\quad(p .100)\end{array}$ & $\begin{array}{l}\text { Proportion of ewes } \\
\text { having shown no } \\
\text { sign of disturbance } \\
\text { in any studied } \\
\text { elements }\end{array}$ \\
\hline \multirow{3}{*}{$\begin{array}{l}\text { Swapping with a newborn } \\
\text { alien lamb, } n=6 \ldots \ldots \\
\text { Swapping with a } 12 \text { to } 24- \\
\text { hrold alien lamb, } n=11 \\
\text { Controls (no swapping), } \\
n \quad 6 \text { ).................. }\end{array}$} & $5.9 \pm 0.6\left(^{a}\right)$ & $0(a)$ & $50\left(a^{a b}\right)$ & $50(a b)$ \\
\hline & $0.3 \pm 0.2\left(^{b}\right)$ & $82\left(^{b}\right)$ & $0\left(^{b}\right)$ & $0\left(^{b}\right)$ \\
\hline & $5.6 \pm 0.4\left(^{a}\right)$ & $O\left({ }^{a}\right)$ & $100\left(^{(a)}\right.$ & $100\left(^{a}\right)$ \\
\hline
\end{tabular}

Same superscript in parenthesis of a same column indicates there is no significant difference between those values at the 5 p. 100 level. 
$P=0.03$ and $P=0.0001$, respectively). In addition, a mother-young contact of 30 min before the swapping also appeared to affect the acceptance of alien lambs. Although the group in which the lambs were swapped with an alien newborn did not differ significantly from the control group, the ewes showed a tendancy to accept an alien lamb less readily than the control $(3.6$ vs $6 / 6 ; P=0.09)$. Such a trend was not observed when the lambs were exchanged at parturition (see table $1: 10 / 11$ vs 23/23; $P=0.3$ ). Also, more alien lambs (newborn or «aged ») exchanged at parturition were accepted by ewes than when the exchange was effected $30 \mathrm{~min}$ later (see tables 1 and $2: 3 / 6$ vs $10 / 11$ for newborn alien lambs, $P=0.1 ; 0 / 11$ vs $6 / 16$ for « aged » alien lambs, $P=0.03$ ).

The third group (swapping at the birth of the second lamb; table 3) gave similar results to those observed in the other two groups. Only 2 ewes out of 10 accepted an " aged » alien in the place of their second lamb (vs $8 / 11$ in the case of a newborn ; $P=0.02$; and $17 / 17$ in the controls). The behaviour of the ewes whose second lamb was swapped with a newborn alien also differed slightly from the behaviour of the controls towards their own second lumb, mainly in the duration of licking $(P<0.05$, table 3 ) ; the proportion of ewes accepting the alien without signs of disturbance also differed $(8 / 11$ vs $17 / 17 ; P=0.05)$.

TABLE 3

Effect of exchanging the lamb of a dam with an alien lamb on maternal behaviour :

C. Swapping at the birht of the second lamb (multiple births only)

\begin{tabular}{|c|c|c|c|c|}
\hline Group & $\begin{array}{l}\text { Licking time } \\
\text { over a period } \\
\text { of } 10 \mathrm{~min} \text {. } \\
\text { (in min. } \pm \mathrm{SE} \text { ) }\end{array}$ & $\begin{array}{l}\text { Incidence } \\
\text { of aggressive } \\
\text { behaviour } \\
\text { (p. 100) }\end{array}$ & $\begin{array}{l}\text { Proportion of } \\
\text { ewes bleating } \\
\text { low pitch only } \\
\text { (p. 100) }\end{array}$ & $\begin{array}{c}\text { Proportion of ewes } \\
\text { having shown no } \\
\text { sign of disturbance } \\
\text { in any studied } \\
\text { elements }\end{array}$ \\
\hline \multirow{3}{*}{ 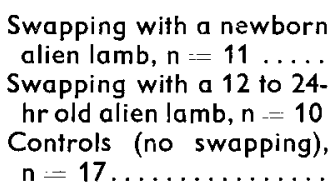 } & $2.5 \pm 0.4\left({ }^{a}\right)$ & $18(a)$ & $82\left(a^{b}\right)\left({ }^{1}\right) *$ & $73^{(a)}\left(^{2}\right)$ \\
\hline & $0.2 \pm 0.1\left(^{v}\right)$ & $70\left(^{b}\right)$ & $40\left(^{a}\right) *$ & $20(")$ \\
\hline & $4.6 \pm 0.8\left(^{c}\right)$ & $0\left(^{a}\right)$ & $100\left(^{b}\right)\left(^{(1)}\right.$ & $100\left(^{c}\right)\left({ }^{2}\right)$ \\
\hline
\end{tabular}

Same superscript in parenthesis of a same column indicates there is no significant difference between those values at the 5 p. 100 level.

* and $\left({ }^{1}\right)=P=0.06$, one-tailed exact probability,

$\left({ }^{2}\right)=\mathbf{P}=0.05$, one-tailed exact probability.

It is clear from the results of these three groups that the newborn lamb was markedly more attractive to a parturient ewe than a 12 to 24 -hr old lamb. Thus, some characteristics of the lamb at birth influenced the manifestation of maternal behaviour. The results of the second group, in which the lambs were swapped after an initial 30 min contact, indicated that, in addition, discriminative behaviour was already established in some dams at that time, as suggested by Smith, Van Toller and Boyes (1966) and Poindron (1980). On the other hand, the above results in no way permit 
conclusions on the long-term development of the acceptance of an alien. Lastly, it is interesting to note that in the case of twin births (group 3), the ewes seemed to distinguish between their second lamb and a newborn alien presented at the moment of the birth of the second lamb, since they licked the alien newborn lamb less than they did their own second lamb. It is not known whether this was due to some methodological artefact or whether it is of biological significance.

\section{Experiment II : Influence of the age of the lamb when studying the sensitive period.}

After parturition, maternal responsiveness towards the lamb fades rapidly if it is removed at birth (Hersher ef al., 1963 ; Smith ef al., 1966). It would appear that maternal behaviour has already disappeared after $4 \mathrm{hrs}$ in about 50 p. 100 of dams when the lamb is removed at birth, and the proportion of ewes accepting their lamb decreases as a function of the length of separation (Poindron, Martin and Hooley, 1979). However, these studies present a methodological difficulty. For example, in an earlier study (Poindron et al., 1979), ewes were tested with their own lambs after separations of 4, 12 or $24 \mathrm{hrs}$. In the light of the present results (see Experiment 1), the fading of maternal responsiveness reported previously might be partly due to a decrease in the attractiveness of the offspring to the mother. To clarify this point, the fading of maternal behaviour in ewes totally separated from their lambs for $12 \mathrm{hrs}$ was tested with either a newborn alien lamb or their own 12-hr old lamb. Multiparous Préalpes-du-Sud ewes were used and the breeding conditions were the same as in Experiment I ; lambing was induced as previously with dexamethasone. The experimental conditions were similar to those described for Merino ewes by Poindron et al. (1979), except that there was no pre-experimental training for human handling since the ewes were accustomed to the experimental locale and to human presence due to the type of management. Twenty-one ewes were tested with a newborn alien lamb and 34 with their own 12-hr old lamb. Only ewes giving birth to one lamb were used in this experiment. An ewe was considered to accept her lamb if, after half an hour of testing, she had suckled the lamb. All newborn lambs had clearly attempted to suck within that time.

Ten out of the 21 females tested with newborn lambs accepted them, while the others remained indifferent or actively rejected them. Of the group of ewes tested with their own 12-hr old lambs, only 8 out of 34 accepted them. The calculated probability for the difference between the two groups was $\mathbf{P}=0.06$. Therefore, it is possible that the characteristics of the lamb influence the estimation of the length of the sensitive period. However, the existence of that period is a well established fact, since ewes separated for $24 \mathrm{hrs}$ from their lamb, 2 to 4 days after lambing, remain maternal, whereas the same separation at birth results in the fading of maternal responsiveness (Poindron et al., 1979). Further evidence for the existence of a change in responsiveness inherent in the mother is that the proportion of post-parturient females accepting a lamb after a given length of separation can be modified by administering oestrogens to the mother, although the age (and thus attractiveness) of the lamb remains constant (Poindron et al., 1979). 


\section{Experiment III : Influence of information provided by the lamb during the sensitive period on the establishment of maternal behaviour.}

The post-partum period during which maternal behaviour is under hormonal control is limited to a few hours. During that time, the newborn lamb provides cues which stimulate the dam to remain maternal beyond the initial limits of the sensitive period (Poindron et al., 1979). To assess the relative importance of various cues provided by the lamb, maintenance of maternal behaviour was studied in ewes when they were partially deprived of the stimulation of the lambs.

This experiment used aged (thus presumably multiparous) Merino ewes (except for 13 ewes of group 1 and the 11 ewes of group 2 which were multiparous Préalpes mothers, groups 1, 2) kept inside from two weeks before lambing and accustomed daily during that time to human handling and to the experimental locale, as described in Poindron ef al. (1979). The ewes were induced to lamb with dexamethasone. They were allocated to five groups. The treatment starded at parturition in all groups and lasted $12 \mathrm{hrs}$.

Group 1. - Ewes were kept next to their own lamb placed in a $45 \mathrm{~cm}$ high weldmesh pen, so that the lamb could be licked but not suckled ( 20 females). Other ewes and lambs were in an adjacent pen.

Group 2. - Conditions were similar to those of group 1, but the lamb was placed in a pen closed on all sides with double-weldmesh walls ( $50 \mathrm{~mm}$ between walls), so that the ewe could not suckle nor lick the lamb (11 females).

Group 3. - Ewes were introduced into a room divided into two pens 1 meter apart. Dams (at least 3 females at any time) were placed in one pen and lambs in the other (14 females).

Group 4. - A room was divided into 3 individual pens. The mother was placed next to her lamb in each pen. The lamb was in an airtight box $(60 \times 60 \times 60 \mathrm{~cm})$ with a plexiglass side so that the ewe could see and hear the lamb but not smell it (14 females). As in group 3, three females at a time were always kept together in the room.

Group 5. - Twenty-three ewes undergoing a total mother-young separation were used as controls. Eight of those females were not induced to lamb, while the remaining 15 were treated with dexamethasone. The 23 ewes underwent a 12-hr mother-young separation, as previously reported by Poindron et al. (1979).

The results are summarized in table 4 . The ewes deprived of suckling only (group 1) all remained maternal (20/20) as did those deprived of suckling and licking (group $2 ; 11 / 11)$. The proportion of ewes accepting their lambs in those two groups was significantly higher than in the control group (group 5 ; total separation ; $P<0.01$ ). In contrast, the ewes which could not smell their lambs did not differ significantly from the controls (group 4 vs group $5 ; 2 / 14$ vs $7 / 23 ; P=0.94$ ), despite the fact that they could see and hear their lambs. Similar results were found when the ewes were kept 1 meter away from their lambs, that is, where olfactory perception of the cues provided by the lamb was questionable ( $g$ roup $3 ; 7 / 14$ vs $7 / 23 ; P=0.2$ ). However, it is interesting to note in this group, where some olfactory perception may have occurred, that 
the proportion of acceptances was situated midway between those ewes which could undoubtedly smell their lambs (groups 1,2 ) and those of the group which could not (group 4). This difference between group 3 and groups 1 or $2(P<0.01$ ) was significant and that between groups 3 and $4(P=0.051)$ nearly reached significance.

\section{TABLE 4}

Effects of various types of partial mother-young contacts on the acceptance of the lamb by its dam (ewes induced to lamb with dexamethane, single births only)

Groups
Proportion of spontaneous acceptances (within $30 \mathrm{~min}$ of the beginning of the test)
1. Lamb in contact with dam but no suckling.......

2. Lamb next to the ewe $(50 \mathrm{~mm}$.) but no suckling

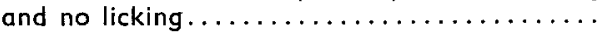

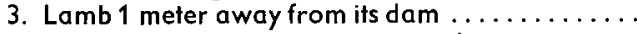

4. Lamb in a airtight box next to its $d a m . . . \ldots \ldots$

5. Total mother-young separation ............
$20 / 20(a)$

$11 / 11(a)$

$7 / 14\left({ }^{b}\right)(1)$

$2 / 14\left({ }^{b}\right)(1)$

$7 / 23(b)$

All treatments started immediately at parturition and lasted 12 hrs.

(1) $\mathrm{P}=0.051$, one-tailed exact probability.

Same superscript in parenthesis for two proportions indicates there is no significant difference between those proportions at the 5 p. 100 level.

These experiments strongly suggest that olfactory cues provided by the young are important for the maintenance of maternal behaviour beyond the limits of the sensitive period. However, they do not determine whether the perception of olfactory information alone is sufficient, or whether other sensory cues are also necessary to the mother.

\section{Conclusion.}

Although the three experiments reported here each had a specific aim, they all underline in some way the important role played by the newborn lamb in the regulation of maternal behaviour during the hours following parturition. Temporary maternal responsiveness is largely under hormonal control in multiparous ewes (Le Neindre, Poindron and Delouis, 1979 ; Poindron and Le Neindre, 1979 ; Poindron et al., 1979). This insures the establishment of the initial contact between the mother and the newborn at the time of parturition. From then on, the lamb plays an increasingly important role in the further development of maternal behaviour. Results from the first experiment indicate that some characteristics of the newborn, already fading within 12 to $24 \mathrm{hrs}$ after birth, influence the initial manifestation of adequate maternal behaviour in the parturient ewe. One obvious difference between a newborn and an «aged» lamb is the presence of placental fluids in the lamb's coat at birth. The strong interest of lambing ewes in these fluids is well known (Collias, 1956 ; McBride ef al., 1967 ; Arnold and Dudzinski, 1978), and thus they are certainly a factor making the newborn attractive to the dam. Another possible difference between a newborn and a 24-hr old lamb is their behaviour, which varies in several ways. For example, a 
few « aged » lambs showed little interest in the ewes, suggesting that they might have been disturbed by swapping, or that they might already have established a preferential bond with their own dam, or even learned to recognize the behaviour of an alien ewe (rejection posture) as compared to that of their own dam. Lamb behaviour could also be involved in another way since "aged » lambs are much more active than newborn lambs, and therefore the degree of motor activity could be a further element influencing acceptance by the mother. The observation of primiparous parturient ewes tends to support this hypothesis. Some dams shows abnormal maternal behaviour at the first parturition, butting the newborn (Hulet et al., 1975 ; Raksanyi, 1979). It would seem that ewes tend to butt their lamb away mainly when it tries to stand up or approach, but rarely when it lies down or stands still, suggesting that the relative immobility of the lamb favours its initial acceptance.

Another hypothesis has been advanced to explain the preference of nanny-goats for newborn alien kids rather than for «aged » alien kids (Gubernick, CorbeauJones and Klopfer, 1979). The dams would mark their kids first by licking (contamination of the coat with rumen microfauna) and later on by milk absorption. This hypothesis does not appear entirely satisfactory, at least in sheep, since the rejection of newborn lambs was observed in Experiment I, group 2 with swapping at $30 \mathrm{~min}$. Furthermore, in the study of the sensitive period (Experiment II), some « aged 》 lambs which had been licked by non-selective anosmic lactating ewes and suckled by them, were accepted, while some newborn lambs were rejected.

The results of the second experiment reported in this paper also indicate that the characteristics of the newborn are of importance when studying the fadings of maternal behaviour. When the length of the sensitive period is studied with « aged » lambs ( $<4 \mathrm{hrs}$ in about 50 p. 100 of females ; Poindron et al., 1979), it is probably underestimated. In fact, it seems essential when studying the formation of mother-young relationships to bear in mind that the sensitive period results from the combination of two factors, one inherent in the mother (maternal responsiveness) and the other inherent in the lamb (newborn attractiveness). At parturition, both the dam's responsiveness and the lamb's attractiveness are maximal, thus insuring the satisfactory manifestation of maternal behaviour.

Nevertheless, as emphasized above, the young change rapidly and the ewe cannot rely permanently on the newborn characteristics which are important for the initial manifestition of maternal behaviour. From the results of Experiment III, it appears that olfactory cues provided by the lamb are important in allowing the adjustment of maternal behaviour to the changing characteristics of the offspring, since only ewes which could smell their lambs stayed clearly maternal, although the lambs were $12 \mathrm{hrs}$ old (that is, «aged» as defined in Experiment l) at the time of testing. We conclude that the lamb is indispensable to the mother, enabling her to adjust her maternal behaviour and therefore to display appropriate responses at any moment during the maternal cycle. This role of the young has already been well demonstrated in laboratory animals (Rosenblatt and Lehrman, 1963 ; Noirot, 1972) and may merit consideration when studying long-term development of the mother-young bond, such as the process of weaning. 
Acknowledgments. - The authors wish to thank Messrs. Mirman, Petrequin, Delouis and all the staff of the experimental farm at Brovessy where part of this work was carried out, as well as the staff and the post-graduate students of the Department of Animal Science (University of Western Australia) for their help in executing the third experiment reported in this paper. Mr. J. B. Williams is thanked for correcting the manuscript. Part of this research was supported by a grant from the Australian Meat Research Committee.

Résumé. L'importance du jeune dans la régulation du comportement maternel de la brebis parturiente a été étudiée dans trois expériences. Dans une première étude, le comportement spontané de la brebis a été observé à la parturition quand à des brebis on échangeait leur agneau avec un agneau étranger nouveau-né ou âgé de 12 à $24 \mathrm{~h}$. Des perturbations minimes ont été observées lorsque l'échange était réalisé avec un agneau étranger nouveau-né. Par contre, des différences significatives évidentes ont été notées lorsque l'agneau étranger était âgé de 12 à $24 \mathrm{~h}$. Dans une seconde expérience, il a été trouvé que des brebis séparées de leur agneau dès la naissance pour une durée de $12 \mathrm{~h}$ acceptaient plus facilement un agneau étranger nouveau-né que leur propre jeune âgé de $12 \mathrm{~h}$ au moment du test. Enfin, dans une dernière expérience, des brebis étaient maintenues en contact partiel avec leur agneau pendant $12 \mathrm{~h}$ à partir de la parturition. II ressort des résultats que seules les brebis qui pouvaient sentir leur jeune sont toutes restées maternelles jusqu'au moment du test. II apparaît en conclusion qu'il existe des caractéristiques propres au nouveau-né qui sont nécessaires pour le bon développement du comportement maternel à la parturition.

\section{References}

ALEXANDER G., 1960. Maternal behaviour in the Merino ewe. Proc. oustr. Soc. Anim. Soc. Prod., 3, 105-114.

ARNOLD G. W., DUDZINSKI M. L., 1978. Maternal behaviour, 137-165. In Ethology of free ranging domestic animals. Chapt. 5. Elsevier Sci. Publ. C., Amsterdam.

ARNOLD G. W., MORGAN P. D., 1975. Behaviour of the ewe and lamb at lambing and its relationship to lamb mortality. Appl. Anim. Ethol., 2, 25-46.

BOSC M. J., 1974. La parturition provoquée chez les mammifères domestiques, 1-24. In BOSC M. J., PALMER R., SUREAU Cl., Avortement ef Parturition provoquée. Masson ef Cie Ed.

COLLIAS N. E., 1956. The analysis of socialisation in sheep and goats. Ecology, 37, 228-239.

GUBERNICK D. J., CORBEAU-JONES K., KLOPFER P. H., 1979. Maternal imprinting in goats ? Anim. Behav., 27, 314-315.

HERSHER L., RICHMOND J. B., MOORE A. U., 1963. Maternal behaviour in sheep and goats. In RHEINGOLD H. L., Maternal Behavior in mammals, John Wiley and Sons Inc. New York, Chapt. 6, 203-232.

HULET C. V., ALEXANDER G., HAFEZ E. S. E., 1975. The behaviour of sheep. In HAFEZ E. S. E. The Behaviour of domestic animals. Ballière Tindall, London.

LE NEINDRE P., POINDRON P., DELOUIS C., 1979. Hormonal induction of maternal behaviour in non-pregnant ewes. Physiol. Behav., 22, 731-734.

McBRIDE G., ARNOLD G. W., ALEXANDER G., LYNCH J. J., 1967. Ecological aspects of the behaviour of domestic animals. Proc. Ecol. Austr., 2, 133-165.

NOIROT E., 1972. The onset of maternal behavior in rats, hamsters and mice : A selective review. Adv. Stud. Behav., 4, 107-145.

POINDRON P., 1980. Experimental analysis of the onset, establishement and maintenance of maternal behaviour in sheep. Ph. D. Univ. Western Australia. 
POINDRON P., LE NEINDRE P., 1979. Hormonal and behavioural basis for establishing maternal behaviour in sheep. Proceed. 2d int. Symp. Clinical psycho-neuro endocrinology in reproduction. Venice June 3rd-5h 1979. Elsevier-North-Holland. Biomed. Press, 121-128.

POINDRON P., MARTIN G. B., HOOLEY R. D., 1979. Effect of lambing induction on the sensitive period for the establishment of maternal behaviour in sheep. Physiol. Behav., 23, 1081-1087.

RAKSANYI I., 1979. Comparaison du comportement maternal de brebis primipares ou multipares dans trois races différentes. Mém. Fin d'Etudes E.N.S.F.A., Rennes.

ROSENBLATT J. S., LEHRMAN, 1963. Maternal behavior of the laboratory rat. In RHEINGOLD, H. L., Maternal behavior in mammals, Chapt. 1, 8-57. John Wiley and Sons, New York.

SMITH F. V., VAN TOLLER C., BOYES T., 1966. The " critical period " in the attachement of lambs and ewes. Anim. Behov., 14, 120-125. 